IJMS 18 (1), 1-29 (2011)

\title{
THE DETERMINANTS OF INTERNET FINANCIAL DISCLOSURE: THE PERSPECTIVE OF MALAYSIAN LISTED COMPANIES
}

\author{
ALI SALEH ALARUSSI \\ MOHAMAD HISYAM SELAMAT \\ UUM College of Business \\ Universiti Utara Malaysia \\ MUSTAFA MOHD HANEFAH \\ Faculty of Economics \& Muamalat \\ Universiti Sains Islam Malaysia
}

\begin{abstract}
This paper investigates whether Internet Financial Disclosure (IFD) can be explained by the elements of the company's characteristics and dominant personalities in board committees. Ten variables have been tested using data collected from 194 Malaysian listed companies' websites, namely, internationality, leverage, foreign shareholders, information technology (IT) experts, firm's age, number of shareholders, listing status, dominant personalities in the audit committee, chairman of audit and nomination committees, and dominant personalities in the audit and nomination committees. It is found that IT experts, firm's age, number of shareholders and listing status are significantly affected by the level of IFD. However dominant personalities in the audit and nomination committees are negatively related to the level of IFD in Malaysia. The study provides some evidence to support the signalling theory and the cost and benefit hypothesis in relation to Internet disclosure.
\end{abstract}

Keywords: Determinants, Internet Financial Disclosure, listed companies.

\begin{abstract}
Abstrak
Artikel ini mengkaji sama ada pendedahan maklumat kewangan melalui Internet boleh diterangkan oleh elemen ciri-ciri syarikat dan personaliti dominan dalam lembaga pengarah. Sebanyak sepuluh pemboleh ubah telah dianalisis dengan menggunakan data daripada Laman Web 194 syarikat Malaysia yang tersenarai iaitu dari sudut keantarabangsaan, keumpilan
\end{abstract}


(leveraj), pelabur luar, pakar teknologi maklumat, usia syarikat, bilangan pemegang saham, status penyenaraian, personaliti dominan dalam jawatankuasa audit, pengerusi jawatankuasa audit dan pelantikan serta personaliti dominan dalam jawatankuasa audit dan pelantikan. Dapatan kajian ini mendapati faktor pakar teknologi maklumat, usia syarikat, bilangan pemegang saham dan status penyenaraian mempengaruhi tahap pendedahan maklumat kewangan melalui Internet secara signifikan. Walau bagaimanapun, personaliti dominan dalam jawatankuasa audit dan pelantikan berkait secara negatif dengan pendedahan maklumat kewangan melalui Internet di Malaysia. Dapatan kajian ini menyokong teori pemberitahuan dan hipotesis kos serta faedah berkaitan dengan pendedahan melalui Internet.

\section{Introduction}

Since the 1990s, companies are utilizing the Internet as a medium to disclose their information. Currently, the level of Internet disclosure varies between companies worldwide. This phenomenon has attracted many academic researchers in the disclosure field. It is argued that Internet reporting is the efficient instrument to communicate information to external users at a minimum cost. Information on the Internet can be presented in different forms of dynamic presentations such as draws, multimedia, audio, video and others (Ettredge, Richardson \& Scholz, 2002; Ashbaugh, Johnstone \& Warfield, 1999).

Despite the growing usage of the Internet in the financial market, IFD is still at the infancy stage in developing countries such as Malaysia (Hassan, Jaffer \& Johi, 1999; Noor Azizi, Mahamad \& Adon, 2000; Mitchell, Ho \& Pei, 2000; Khadaroo, 2005). This study intends to contribute to this gap by studying the information disseminated via the Internet by Malaysian companies since only a few studies have examined IFD in the Asian countries. The difference between this study and previous studies is that it considers the Malaysian-listed companies' unique variables, namely, size-based listing status (Yatim, Kent \& Clarkson, 2006) and foreign-controlled companies (Mok, Lam \& Cheung, 1992; Lam, Cheung \& Yam, 1994). These characteristics may influence the trend of IFD amongst Malaysian-listed companies. The understanding on the determinants of IFD among Malaysianlisted companies could assist policy makers in improving Internet financial reporting in Malaysia.

Therefore, this paper aims to investigate factors that influence the extent of IFD in Malaysia. The remainder of this paper is structured as follows: Section 2 provides an overview of IFD development, 
while Section 3 reviews the factors that affect IFD. The research method is described in Section 4. Section 5 presents the results of this research. Finally, Section 6 provides the conclusions, limitations, and recommendations for future research.

\section{The Development of Internet Financial Disclosure}

The nature and the extent of the disclosure problem involves a consideration of the persons to whom the disclosure is being made, an assessment of user needs and the medium of disclosure which is used to communicate with the user groups (Kreps, 1990). The main concern is that accounting reports should have information which is necessary to the users so that they would not be misleading (Moonitz, 1961). It has been argued that equity markets require comprehensive and transparent disclosures of the firms' value and their performance in order to run efficiently (Levitt, 1999; Richardson \& Welker, 2001).

Modern corporations have adopted various mechanisms, including voluntary disclosure, to mitigate the effects of information asymmetry. Theoretically, agency theory predicates that as conflicts arise from the separation of ownership and control of a company, shareholders would like to have assurance that their equity is not subjected to any misuse or expropriations by the management. The management, in order to alleviate this problem, undertakes several actions including voluntary disclosures and establishes governance mechanisms (Xiao, Yang \& Chow 2004; Marston \& Polei, 2004). This leads to an increase in the cost of dissemination and management may use other channels to disclose the company's information in order to reduce the agency cost. Empirical studies on Internet voluntary disclosure suggest that managers voluntarily enhance the visibility of their companies' financial profiles to: (1) reduce agency costs or contracting costs (Chow \& Boren, 1987; Debreceny, Gray \& Rahman, 2002 ); (2) reduce the cost of capital (Botosan,1997); (3) enhance the value of the company (King, Pownall \& Waymire, 1990; Yeo \& Ziebart, 1995; Frankel, Johnson \& Skinner, 1999); (4) enhance the level of transparency (Lodhai, 2004); (5) enhance communication with companies' stakeholders (Hassan et al., 1999); (6) record higher market liquidity (Welker, 1995); and (7) increase the interest shown by institutions and analysts in the companies' stocks (Lang \& Lundholm, 1996; Healy, Hutton \& Palepu, 1999). Nazli and Mohd Ghazali (2008) conducted interviews with twenty-seven market participants in Malaysia and found that the existence of other channels of communication is one of the factors influencing voluntary information disclosure in annual reports. 
Portes and Rey (2005) argue that companies started to report via the Internet as traditional paper-based disclosure has its limitations. The increase in global investments and investors results in paper-based disclosure becoming more expensive and limited in capacity to reach investors in timely manner. In contrast, Internet disclosure has been found to be cost effective, fast, flexible in format, and accessible to all types of users within and out of national boundaries (Debreceny, Gray \& Rahman, 2002). Thus, the Internet has more benefits than other media of disclosures such as newspapers, journals or other printing media. The Internet offers easy and equal access to all firms' information and increases the image of the firms through creative and innovative presentation on the website. In other words, the more information disclosed by a firm, the more chances the firm will present itself.

In a more advanced usage of the Internet, some companies employ technological advances to display information such as streaming audio and video on their websites (Rosli Mohammed et al., 2003). Streaming audio allows interested individuals to listen to analysts' conference classes, annual meetings and similar presentations; to broadcast conference calls live, or to provide an archive of presentations from which the Internet user can select. Some companies also provide video together with the streaming audio (Hurtt, Kreuze \& Langsam 2001).

The investors that are concerned with return on investment will not use historical financial data as a means to evaluate companies' future performance. Instead of that, they will search and consider recent and real-time indicators of management competence such as the ability to support and increase customer loyalty and retain and leverage the knowledge of employees (Wheeler \& Elkington, 2001). Internet financial disclosure can also improve timeliness and verifiability (Debreceny et al., 2002). Timeliness is improved by increasing the frequency of disclosure, and verifiability is improved by using hyperlinks to multiple sources of information.

In short, IFD creates effective and interactive communication with the investors. This in turn adds real value to the stakeholders and facilitates the companies in controlling their marketplaces.

\section{The Determinants of Internet Financial Disclosure}

A large number of studies in different countries attempted to study Internet reporting such as Ettredge et al. (2002) in the USA, Marston

4 IJMS 18 (1), 1-29 (2011) 
and Polei (2004) in Germany, Laswad, Fisher and Oyelere, (2005) in New Zealand, Marston (2003) in Japan, Xiao et al. (2004) in China, Khadaroo (2005) in Malaysia and Singapore, and Debreceny et al. (2002) in 22 countries. However, only a few of them examined factors that influence the extent of Internet reporting. Some studies examined only one factor such as company size (Allam \& Lymer, 2003) or industry type (Hussainey \& Al-Nodel, 2008). Other researchers examined two factors such as company size and capital ownership (Pirchegger \& Wagenhofer, 1999) or company size and industry type (Craven \& Marston, 1999). Several researchers such as Xiao et al. (2004), Tariq (2001), and Da Silva and De Lira (2004) examined many factors. They came up with different determinants and factors that affect the extent of IFD. These determinants were in the form of internal determinants such as firm size, internationality, leverage, shareholders, IT experts and corporate governance mechanism or external determinants such as regulations and government roles. However, there was no consistency in the findings due to the different nature of the studies.

In this study the researchers examine the relationship between IFD and internal determinants from the Malaysian perspective as the aim of this research is to investigate IFD from the organizational perspective. Emulating Xiao et al. (2004), Tariq (2001), and Da Silva and De Lira (2004), the factors of internationality, leverage, foreign shareholders, IT experts, firm's is age, number of shareholders, and corporate governance mechanism are selected. These factors are examined because they have significant effects on IFD in other countries (Xiao et al., 2004; Tariq, 2001; Da Silva \& De Lira, 2004). The factors also have a similarity with the Malaysian company structure (Haniffa \& Cooke, 2002). For corporate governance mechanism, the researchers examine the factors of dominant personalities in the audit committee, chairmen of audit and nomination committees, and dominant personalities in the audit and nomination committees. These mechanisms are selected because they are critical issues in Malaysian corporate governance (Haniffa \& Cooke, 2002). As Bursa Malaysia has two boards, the listing status factor is proposed as one of the determinants. The descriptions of each determinant are offered in the following ten subsections.

\section{Internationality}

When an organization becomes famous and is known globally, the extent of its information disclosure will be increased due to the increase in foreign stakeholders and the obligation to fulfil different 
requirements and regulations in different countries (Bureau \& Raffournier, 1989; Susanto, 1992; Cooke, 1992; Meek, Roberts \& Gray, 1995; Raffournier, 1995; Hashim \& Mohd Saleh, 2007). This in turn, requires multinational companies to voluntarily disclose more financial and non-financial information for two reasons: (1) to eliminate information asymmetry that rise due to the existence of worldwide scattered users; and (2) to fulfil the minimum regulation requirements of different countries that the company has operations in and thereby many stakeholders (Debreceny et al., 2002). In addition, the financial reports need to be prepared in many versions to fulfil the language diversity of worldwide users.

Multinational companies are always the screen of many interested investors who would like to optimize return on investment (Marston, 2003). According to them, multinational companies are always more transparent in disclosing information than local companies. From the organizational perspective, multinational status provides an opportunity to lower the cost of capital due to strong image and reputation amongst interested investors worldwide. These positive image and reputation lead multinational companies to voluntarily disclose more financial and non-financial information (Debreceny et al., 2002; Marston, 2003). This higher disclosure is made to alleviate information asymmetry and build strong image and reputation amongst investors.

To fulfil the above worldwide demands using paper-based disclosure is not economical. This is because paper-based disclosure is more expensive and limited in capacity to reach worldwide investors in timely manner. In contrast, Internet disclosure has been found to be cost effective, fast, flexible in format, and accessible to all types of users within and out of national boundaries (Debreceny et al., 2002). Marston and Polei (2004) stated that Internet disclosure reduces disclosure costs because there is no need to involve the printing media, such as newspaper and journals, which is very expensive due to the many countries involved. Worldwide users also create a situation where a group of users require similar information to make decisions. IFD is considered as the best solution to fulfil the higher information disclosure need of worldwide users as it reduces repeating work, which is inherent of paper-based reporting (Oyelere, Laswad \& Fisher, 2003). In addition, since it is very difficult for multinational companies to know every interested investor in different countries, it is economical and logical to use the Internet as a medium to disclose information as it provides global access at anytime and at a lower cost (Marston, 2003).

6 IJMS 18 (1), 1-29 (2011) 
Based on the above discussions, this study attempts to examine the impact of internationality on IFD. Internationality is measured by using the exports-on-sales ratio (emulating Garcia and Monterrey, 1992; Raffournier, 1995). Therefore, the proposed hypothesis to be tested is:

H1: The extent of financial disclosure on the Internet is positively related to the level of international activity of the company.

\section{Leverage}

The results of the impact of leverage on the extent of voluntary disclosure are mixed. Naser, Al-Khatib and Karbhari, (2002) and Laswad et al. (2005) found a positive relationship between them. This result supports the argument that more debts in the company's financial capital force the creditors to ask for more information due to higher information asymmetry. However, Haniffa and Cooke (2002), Chow and Boren (1987), Ahmed and Nicholls (1994) and Dichev and Skinner (2002) found no significant association between them. In other words, the creditors will not ask for higher information disclosure when evaluating a loan application of a highly borrowing company. This is because leverage does not represent business risk level (Dichev \& Skinner, 2002). Nevertheless, it is argued that the creditors are able to effectively evaluate the strength and potential of a company if they are provided with adequate voluntary financial and non-financial information.

As the Internet is the most cost-effective medium to enhance voluntary disclosure and in turn level of transparency (Lodhai, 2004; Hassan et al., 1999), it is the cheapest way to fulfil creditors' information requirement and ultimately convince them to approve the loan. On top of this is that the creditors can get access to clients' websites easily and at any time. This facility could increase the image and reputation of the borrowers and, in turn, high credence for them. In other words, IFD can be used as a means to convince the creditors to approve the loan and ultimately increase the company's leverage. Thus this research argues that there is a potential positive relationship between leverage and IFD. This leads to the following hypothesis:

H2: The extent of financial disclosure on the Internet is positively related to leverage.

Previous studies have measured leverage in terms of debt to equity ratio (Roberts, 1992; Katsuhiko, Akihiro, Yasushi \& Tomomi, 2001). Another measurement of leverage is by comparing the total of long- 
term liabilities to the total of assets (Haniffa \& Cooke, 2002; Laswad et al., 2005; Alsaeed, 2005). This study follows the latest measurement, that is by using the percentage of long-term liabilities on total assets. This is because it is the most commonly used measurement in the financial literature (Haniffa \& Cooke, 2002; Laswad et al., 2005; Alsaeed, 2005).

\section{Foreign Shareholders}

Haniffa and Cooke (2002) found a significant positive relationship between foreign ownership and the level of paper-based disclosure. The results support the argument that the higher foreign ownership is in an organization, the higher information asymmetry will be, and, it is critical if the regulations of the investment receiving country are not well understood. This in turn, pushes foreign shareholders to ask for more information, which is initially not required by the regulations, and eventually leads to more voluntary disclosure (Leung, Morris \& Gray 2005). The best way to fulfil that requirement is through the Internet as it is available everywhere (Lodhai, 2004). Xiao et al. (2004), however, found no significant relationship between foreign ownership and Internet disclosure by the companies in China. This discrepancy motivates the researcher to study the impact of foreign ownership on the extent of voluntary disclosure on the Internet in other countries. In other words, this study examines the impact of having foreign shareholders in Malaysian companies on the extent of financial disclosure on the Internet. This variable is measured by using the ratio of the total shares that are owned by foreigners to the total number of issued shares (Haniffa \& Cooke, 2002). Thus the following hypothesis is proposed:

H3: The extent of financial disclosure on the Internet is positively related to the percentage of foreign shareholders.

\section{IT Experts}

The existence of technological services undertaken by IT experts such as web designers and systems analysts in the information system department are necessary if a company intends to offer Internet disclosure (Lodhai, 2004). The responsibility to design and maintain the website such as uploading and updating information is usually given to the IT experts. The website, unlike paper-based reporting, has many IT features and formats such as PDF, hyperlink, audio, video and others that require IT experts to operate. This is to ensure that the website provides the needed information effectively and 
efficiently. Debreceny et al. (2002) examined the association between the existence of technological services and the extent of voluntary disclosure through the Internet and found a significant positive relationship between them. In addition to this, the cost of designing and maintaining the website is high (Joshi \& Jawaher, 2003; Lodhai, 2004) - especially if it is outsourced. Thus, the role of IT experts in the information system department is important to help the company to have a website and disclose its information on it at a minimum cost and to attain ideal IFD practice. In short, there is a potential relationship between the extent of IFD and the existence of IT experts in Malaysian-listed companies. The involved variable is measured by using dummy measurement. The proposed hypothesis is as follows:

H4: The extent of financial disclosure on the Internet is influenced by the existence of IT experts.

\section{Firm Age}

There are some studies that concentrate on time factor as a determinant of voluntary disclosure. For example, Haniffa and Cooke (2002) examined the impact of listing age on the level of voluntary financial disclosure amongst Malaysian-listed companies. The result was quite surprising where listing age showed a high positive correlation with disclosure. A similar result was also obtained by Alsaeed (2005). Camfferman and Cooke (2002) stated that the age of a company has a significant impact on the extent of Internet disclosure. This is because old companies usually have bigger operations in terms of geography, turnover and capital (Haniffa \& Cooke, 2002). To assist them in disseminating financial information to diversified stakeholders, they utilize the electronic version of the annual report (in addition to the printed version) as value-added service to the stakeholders (Debreceny et al., 2002) and as a means to reduce costs (Botosan, 1997). Eventually, the level of disclosure on the Internet is dramatically increased.

As firm's is age has never been tested from the perspective of Internet disclosure, this study aims to examine it by counting the number of operating years since the company was listed on the stock exchange. In other words, the impact of the firm's is age on the extent of IFD will be examined in this research. The proposed hypothesis is as follows:

H5: The extent of financial disclosure on the Internet is influenced by the firm's is age. 


\section{Number of Shareholders}

Oyelere et al. (2003) found out that the spread of shareholding (large number of shareholders in different countries) has a significant positive relationship with the extent of voluntary financial disclosure on the Internet by New Zealand-listed companies. This is normal as the best medium to fulfil each group of shareholders' information needs at a minimum cost is the Internet (Botosan, 1997). A huge number of shareholders, inside and outside a country, will increase the demand for more information. This increase leads to an increase in information asymmetry and ultimately agency cost (Oyelere et al., 2003). To reduce information asymmetry and agency cost to a minimum cost, the management normally opts for Internet disclosure (Chow \& Boren, 1987).

However, the level of IFD in Malaysia might be different. This is because the number of shareholders in many Malaysian-listed companies is relatively small. Claessens, Djankor and Lang (2000) uncovered that Malaysian companies that are controlled by a family has increased from $57.7 \%$ to $67.2 \%$. The phenomenon of a low number of shareholders has made the separation of ownership and control to be limited and in turn reduces the need for Internet disclosure. Nevertheless, Naser et al. (2002) state that there is no significant relationship between the number of shareholders and the extent of voluntary disclosure; thus, reducing the need for IFD. In this case there is a chance that the level of IFD amongst Malaysianlisted companies might be higher in spite of the small number of shareholders. Therefore, it is interesting to examine the impact of the number of shareholders on the level of Internet disclosure from the Malaysian perspective. The following hypothesis is proposed:

H6: The extent of financial disclosure on the Internet is influenced by the number of shareholders.

\section{Listing Status}

In Bursa Malaysia, there are two types of listing boards: the main board and the second board. The main board companies must have a minimum paid-up capital of RM60 million while the second board companies are those that have a minimum paid-up capital of RM40 million (Yatim, Kent \& Clarkson, 2006). The main objective of the second board is to enable the companies that do not meet the main board listing criteria to get capital from the public (Bursa Malaysia, 2010). In other words, most of the second board listed companies are relatively new compared to the main board listed companies.

10 IJMS 18 (1), 1-29 (2011) 
Wong (1996) stated that, as newcomers in the industry, the business operations of second board listed companies are not as complex as that of the main board listed companies and thus require less stringent requirements on transparency. Abdul Samad (2002) said that the competition amongst the main board companies is stiffer than those of the second board as investors are keen on them. In this case, the number of main board investors is much higher than the second board investors. All these phenomena illustrate that the need for more information disclosure is critical amongst main board companies than second board companies. Wallace, Naser and Mora (1994) supported this by discovering a significant positive relationship between listing status and the extent of voluntary disclosure.

Implicit in the above definition of main and second boards is the possible influence of company size on information disclosure. The agency theory and cost-benefit analysis indicate a positive relationship between company size and information disclosure (Craven \& Marston, 1999). Chow and Boren (1987) argue that agency costs are higher in the large companies due to the following reasons: (1) they are under pressure to disclose financial information to avoid speculative trading of their shares (Ku Nor Izah, 2003); (2) they are desperately in need of external funds (Ettredge et al., 2002); (3) they are more complex and therefore information users are asking for more disclosure; and (4) they are more visible in the society and therefore, need to disclose more information to reduce political costs (Marston, 2003). To reduce higher agency costs large companies have to voluntarily disclose more information to increase investors' confidence and ultimately stabilize share price.

From the above discussion it can be seen that there is no contradiction between listing status and company size in terms of their relationship with the increase in information disclosure. Instead both of them are complementary to each other. The authors, however, decided to highlight listing status as the element of study because it had not been tested in previous studies. As the Internet has been found to be cost effective, fast, flexible in format and widely accessible for voluntary disclosure (Debreceny et al., 2002), it is more adorable amongst main board companies (large companies) than second board companies (small companies) of Bursa Malaysia. In other words, this study intends to examine the impact of an organization's listing status in Bursa Malaysia on the extent of voluntary financial disclosure on the Internet. Therefore, the following hypothesis is proposed:

H7: The extent of financial disclosure on the Internet is influenced by a firm's listing status.

IJMS 18 (1), 1-29 (2011) 11 


\section{Dominant Personalities in the Audit Committee}

The role of the audit committee is critical in the decision-making process because it has the authority to examine sensitive issues and irregularities and report to the board with recommendations. The board ultimately makes decision after examining the report meticulously. The primary objective of the audit committee is to assist the board of directors in fulfilling its responsibilities in relation to the accounting and the reporting practices of the company and its subsidiaries and to determine the adequacy of the company's administrative, operating and accounting controls (Haron, Jantan \& Pheng 2005; Cohen, Gayner, Krishnamoorty \& Wrisent, 2007). The audit committee also reviews the adequacy and the effectiveness of the corrective actions that are taken by the management in resolving reported audit issues and discusses the appropriateness of adopted accounting policies and treatment and assumptions that are raised by the external auditors (Collier, 1997). Thus, highlighting the audit committee's views on the company's internal control strength in the financial report, which is voluntary in nature, could increase investors' confidence and ultimately the share price (Cohen et al., 2007).

Although disclosing the company's administrative, operating and accounting controls is a platform for the audit committee to promote financial transparency and in turn might expose management weaknesses and mistakes, its practice is not advisable from the eyes of a person who is holding both the posts of chairman of the company and chairman of the audit committee concurrently. This is evident from Mangena and Pike (2004) who uncovered that if the chairman of the company holds several positions in the company's committees, including the audit committee, the decision on voluntary disclosure was negatively affected. That person may use his/her position to refuse such strategy. This is in tandem with PricewaterhouseCoopers (2000) who said that if the chairman of the company is also the chairman of the audit committee, the independence of the audit committee is being compromised and ultimately affect its function - low voluntary disclosure.

As the Internet is the most cost-effective way for voluntary disclosure (Debreceny et al., 2002), its usage might not be so encouraging under the above circumstance, which is the chairman of the company is also the chairman of the audit committee. Under such a scenario the company will not allow the audit committee to disclose the current strength of its internal control on the website as it would tarnish the reputation of the management. Thus, this study attempts to provide empirical evidence regarding the extent of voluntary financial 
disclosure on the Internet in case the chairman of the board directors is also the chairman of the audit committee of the company. Thus the following hypothesis is proposed:

H8: The extent of financial disclosure on the Internet is influenced if the chairman of the board of directors is also the chairman of the audit committee of the company.

\section{Chairman of the Audit and the Nomination Committee}

The role of the audit committee is as discussed above. On the other hand, the duties of the nomination committee are reviewing annually the attendance and performance of individual directors, reviewing and recommending the compensation of directors, recommending qualified nominees for nomination or election as directors, developing and overseeing corporate governance principles for the corporation and performing other duties that may be assigned to the committee (Vafeas, 1999). In short, the audit and the nomination committees are functioning as a monitoring body for the board of directors.

As a monitoring body, the role of the audit and the nomination committees in the process of deciding the level of information (including voluntary one) to be disclosed in the financial report is quite significant (Vafeas, 1999; Haron et al., 2005; Cohen et al., 2007). Chtourou, Bedard and Courteay (2001) said that if the chairmen of the audit committee and the nominating committee are not the same person, their independence might be enhanced and in turn will support any motion that aims to increase the company's transparency, including voluntary disclosure. However, if the chairman of the audit and the nomination committee is the same person, there is a tendency that he/she will collaborate with the board of directors to conceal any misuse or expropriations by the management. To reduce negative perception amongst shareholders on this matter, the board of directors increases voluntary disclosures and appoints different chairman for the audit and the nomination committees (Xiao et al., 2004; Marston \& Polei, 2004). This eventually leads to the increase in cost of information dissemination and the company may use other channels to disclose information in order to reduce the agency cost. Empirical studies on voluntary disclosure suggest that managers voluntarily enhance the visibility of their companies' financial profiles through the Internet (Debreceny et al., 2002; Lodhia, 2004; Hassan et al., 1999). Thus this research argues that there is a potential relationship the between chairmen of the audit and the nomination committees and IFD. Thus the following hypothesis is proposed:

IJMS 18 (1), 1-29 (2011) 13 
H9: The extent of financial disclosure on the Internet is influenced if the chairman of the audit committee is also acting as the chairman of the nomination committee in the corporation.

\section{Dominant Personalities in the Audit and the Nomination Committees}

As discussed above, there is a clear demarcation between the function of the audit committee and the nomination committee. Each committee is responsible for critical and sensitive tasks and therefore must be separated. This is to ensure that the quality of the company's internal control is always at a satisfactory level. The chairman of the company, on the other hand, is responsible for ensuring that the board is always running effectively, the organizational members obtain relevant information and the company's policies are always observed. It is expected that independency might be lower if the chairman of the company is also holding the position of chairman of both the audit and the nomination committees. As the disclosure decision is under the responsibility of the chairman of the company, appointing him/ her as the chairman of both the audit and the nomination committees may negatively affect the extent of disclosure. This is because that strategy causes the level of internal monitoring to be low, and a lack of balance of power (Shivdasani \& Yermack, 1999). As the Internet is the most cost-effective way for voluntary disclosure (Debreceny et al., 2002), its usage might not be so encouraging under the circumstance where the chairman of the company becomes the chairman of the audit and the nomination committees. Thus this study attempts to provide empirical evidence regarding the extent of voluntary financial disclosure on the Internet in case the chairman of the board directors is also the chairman of the audit and the nomination committees of the company. Thus the following hypothesis is proposed:

H10: The extent of financial disclosure on the Internet is influenced if the chairman of the board of directors is also the chairman of the audit and the nomination committees of the company.

\section{Research Design}

The authors, in this study, intend to examine the determinants of IFD by Malaysian public-listed companies on the Bursa Malaysia's main and second boards. The data for this research is secondary in nature and obtained from two sources: (1) the companies' websites; and (2) the companies' annual reports. Since the study is related to Internet disclosure, only companies that have websites will be selected as the 
population of the study. The total number of companies that have websites is 505 out of 849 , which represents $59 \%$. Based on Sekaran's (2000) schedule for sampling, 201 out of 505 companies that have websites are chosen randomly after excluding financial companies due to their different regulations. Since the number of companies under each industry is not similar, the disproportionate stratified random sampling is argued to be the most appropriate sampling technique in this research (Sekaran, 2003).

The websites are either linked to Bursa Malaysia or individual websites. The data are collected during the second half of 2006. The explanation of the data is as follows:

- $\quad$ The data for the dependent variables consist of 15 items (most frequent items used in the earlier studies) that represent the index for the financial disclosure (Table 1 shows a sample of the earlier studies that was used to extract the items). The disclosure index is adopted from the different published academic papers. A score sheet is utilized to determine the score of the level of disclosure amongst the selected companies. These items represent the financial information that is disclosed through the Internet annual report, Internet quarterly report and other places on the website. It is recorded one (1) if the company discloses the item on its website and zero (0) if does not. In short, the score sheet is filled up according to the disclosed items on the companies' websites.

- $\quad$ The data for the independent variables are extracted from the companies' 2005 annual reports. Several score sheets are used to measure each of the independent variables according to its scale of measurements (nominal, ordinal, interval and ratio).

Table 1

Index Items of Financial Information Disclosed on the Internet: A Comparison with Prior Studies

\begin{tabular}{llllllllllll}
\hline $\mathrm{N}$ & Items & A & B & C & D & E & F & G & H & I & J \\
\hline 1 & Financial highlights & 1 & & & 1 & 1 & 1 & 1 & 1 & \\
2 & Current press release or news & 1 & 1 & 1 & 1 & & 1 & 1 & \\
3 & Current share price & 1 & 1 & 1 & 1 & & 1 & 1 & \\
4 & Share performance chart & & & & & & & & 1 \\
\hline & & & & & & & (continued)
\end{tabular}

IJMS 18 (1), 1-29 (2011) 15 


\begin{tabular}{|c|c|c|c|c|c|c|c|c|c|c|}
\hline $\mathrm{N}$ & Items & A & B & $\mathrm{C}$ & $\mathrm{D}$ & $\mathrm{E}$ & $\mathrm{F}$ & & $\mathrm{H}$ & I J \\
\hline 5 & Operation review & & & & & & & & & 1 \\
\hline 6 & Financial review & & & & 1 & & & & & 1 \\
\hline 7 & Financial calendar & & & & 1 & & & & & 1 \\
\hline 8 & Annual Report & & & 1 & 1 & & 1 & 1 & & \\
\hline $8-1$ & Directors and Management Report & & 1 & 1 & & 1 & 1 & 1 & 1 & \\
\hline $8-2$ & Balance Sheet & 1 & 1 & 1 & 1 & 1 & 1 & 1 & 1 & \\
\hline $8-3$ & Income Statement & 1 & 1 & 1 & 1 & 1 & 1 & 1 & 1 & \\
\hline $8-4$ & Cash Flow Statement & 1 & 1 & 1 & 1 & 1 & 1 & 1 & 1 & \\
\hline $8-5$ & Statement of Shareholders' equity & & & & & 1 & 1 & 1 & 1 & \\
\hline $8-6$ & Accounting Notes & 1 & 1 & 1 & 1 & 1 & 1 & 1 & 1 & \\
\hline $8-7$ & Auditor's Report & & 1 & 1 & 1 & 1 & 1 & 1 & 1 & \\
\hline $8-8$ & Segmental Report by Region & & & 1 & & & 1 & 1 & & \\
\hline $8-9$ & Shareholder structure & & & & & & 1 & & & \\
\hline 9 & Annual Report for the past years & & & & & & 1 & 1 & & \\
\hline 10 & Half-year Report & 1 & 1 & & & & 1 & 1 & & \\
\hline 11 & Quarterly Report & & & & 1 & & & 1 & & \\
\hline 12 & Balance Sheet in Quarterly Report & & & & & & & 1 & 1 & \\
\hline 13 & Statement of Income in Quarterly Report & & & & & & & 1 & 1 & \\
\hline 14 & Cash Flow Statement in Quarterly Report & & & & & & & 1 & 1 & \\
\hline 15 & Accounting notes in Quarterly Report & & & & & & & 1 & 1 & \\
\hline
\end{tabular}

A= Deller et al. (1999), B= Pirchegger and Wagenhofer (1999), C= Debreceny et al. (2002), D= Ettredge et al.(2002), E= Marston (2003), F= Marston and Polei (2004), G=Xiao, Yang, Chow (2004), $\mathrm{H}=$ Alarussi (2005), I= Fathilatul (2005), J= Menes-Da-Silva and Christencen (2004).

However seven companies are excluded from the sample because they show outliers in the analysis. This is because any company that shows more than 3.00 in the standardized residual, the company is omitted (Sekaran, 2000). The regression model is utilized to find out the results of this study and this is in tandem with the previous studies (e.g. Chen \& Jaggi, 2000; Ho \& Wong, 2001; Camfferman \& Cooke, 2002; Archambault \& Archambault, 2003; Oyelere et al., 2003; Marston \& Polei, 2004; Gul \& Leung, 2004; Laswad et al., 2005).

\section{Results}

Descriptive statistics, such as frequency distributions, cross tabulations and measures of central tendency, represent the frequency of occurrence of each score value (Sekaran, 2000). The skewness and 
kurtosis ratios are also calculated to check whether the dependent variable is normally distributed. According to Sekaran (2000), both skewness and kurtosis values must be between $+/-2$ before one variable can be declared as normally distributed. Table 2 shows that the value of skewness and kurtosis of IFD is 0.219 and -1.462 . The standard errors of skewness and kurtosis values are 0.175 and 0.347 for IFD. All these figures show that normality exists in the dependent variable, and therefore multiple regression analysis can be applied on it.

Table 2

Descriptive Statistics for Dependent Variable

\begin{tabular}{lccc}
\hline Statistics & IFD $^{*}$ & Statistics & IFD \% \\
\hline Mean & 6.080 & Skewness & 0.219 \\
Standard Deviation & 4.782 & SE Skewness & 0.175 \\
SE Mean & 0.343 & Kurtosis & -1.462 \\
Minimum & 0.00 & SE Kurtosis & 0.347 \\
Median & 5.00 & & \\
Maximum & 15.00 & & \\
\hline
\end{tabular}

* Financial Disclosure Index

The frequency for IFD index items is shown in Table 3. From Table 3 it can be seen that $60 \%-63 \%$ of companies disclose some financial information on the websites. $62.9 \%$ of the companies disclose both current release and news operation review items. $60.8 \%$ of the companies disclose their annual reports and $58.8 \%$ of the companies disclose financial highlights item. These are the most common disclosed items on the websites. This is followed by the annual reports for the past years (51\%), quarterly reports $(46.9 \%)$ and its contents such as statement of income, balance sheet, cash flow statement and accounting notes. However, only $12.4 \%$ companies are concerned with half year reports and $7.7 \%$ are concerned with performance charts. As that information is critical for the investors, the finding shows a significant deficiency in the style of IFD amongst Malaysianlisted companies.

Executing the bivariate correlation procedure on the research data generates the correlation amongst the independent variables and between the independent variables and the dependant variable. This is illustrated in the following Table 4. As stated above, Pearson 
product-moment correlation coefficient " $\mathrm{r}$ " is computed. A relatively high correlation amongst the independent variables is found and considered as a presence of multicollinearity which should be eliminated before any further analysis is undertaken such as regression analysis. Therefore, in order to detect the severity of multicollinearity, the variance inflation factors (VIFs) method is utilized and the result of the test shows that no multicollinearity problem exists amongst the predicted variables as the largest VIF value is 5.672, which is far below the maximum threshold (VIF $=10)$ (as suggested by Hair, Anderson, Tatham \& Black, 1998); and, therefore it is possible to run regression analysis.

Table 3

The Frequency of Internet Financial Disclosure Index

\begin{tabular}{|c|c|c|c|c|c|c|c|}
\hline $\mathrm{N}$ & $\begin{array}{c}\text { Financial } \\
\text { Characteristics }\end{array}$ & Frequency & Percent & $\mathrm{N}$ & $\begin{array}{c}\text { Financial } \\
\text { Characteristics }\end{array}$ & Frequency & Percent \\
\hline 1 & $\begin{array}{l}\text { Current } \\
\text { release or } \\
\text { news }\end{array}$ & 122 & 62.9 & 9 & $\begin{array}{l}\text { Cash flow } \\
\text { statement in } \\
\text { Quarterly } \\
\text { report }\end{array}$ & 80 & 41.2 \\
\hline 2 & $\begin{array}{l}\text { Operation } \\
\text { review }\end{array}$ & 122 & 62.9 & 10 & $\begin{array}{l}\text { Accounting } \\
\text { notes in } \\
\text { Quarterly } \\
\text { report }\end{array}$ & 66 & 34 \\
\hline 3 & Annual report & 118 & 60.8 & 11 & $\begin{array}{l}\text { Current share } \\
\text { price }\end{array}$ & 47 & 24.2 \\
\hline 4 & $\begin{array}{l}\text { Financial } \\
\text { highlights }\end{array}$ & 114 & 58.8 & 12 & $\begin{array}{l}\text { Financial } \\
\text { review }\end{array}$ & 31 & 16 \\
\hline 5 & $\begin{array}{l}\text { Annual } \\
\text { reports for the } \\
\text { past years }\end{array}$ & 99 & 51 & 13 & $\begin{array}{l}\text { Financial } \\
\text { calendar }\end{array}$ & 28 & 14.4 \\
\hline 6 & $\begin{array}{l}\text { Quarterly } \\
\text { report }\end{array}$ & 91 & 46.9 & 14 & $\begin{array}{l}\text { Half year } \\
\text { report }\end{array}$ & 24 & 12.4 \\
\hline 7 & $\begin{array}{l}\text { Statement } \\
\text { of Income } \\
\text { in Quarterly } \\
\text { report }\end{array}$ & 81 & 41.8 & 15 & $\begin{array}{l}\text { Share } \\
\text { performance } \\
\text { chart }\end{array}$ & 15 & 7.7 \\
\hline 8 & $\begin{array}{l}\text { Balance sheet } \\
\text { in Quarterly } \\
\text { report }\end{array}$ & 80 & 41.2 & & & & \\
\hline
\end{tabular}

18 IJMS 18 (1), 1-29 (2011) 


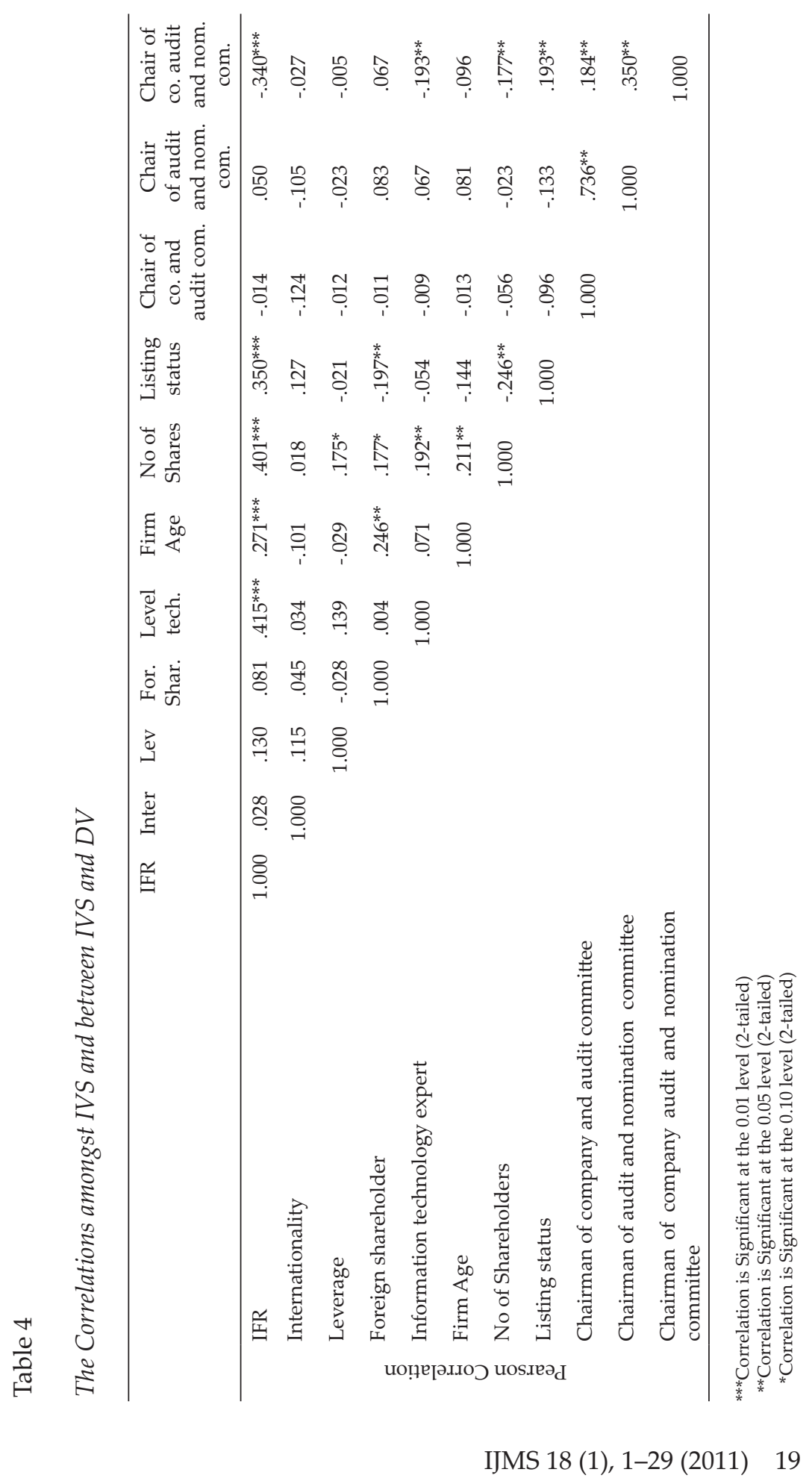


In tandem with the previous studies of voluntary disclosure, (e.g. Cooke, 1989; Hossain, Tan \& Adams 1994; Raffournier, 1995), and due to one dependent variable and ten independent variables, multiple regression analysis is used to test the hypotheses. The results from the regression show that several variables have significant positive relationships with IFD. These variables are IT experts, firm is age, number of shareholders and listing status. However, dominant personalities in the audit and nomination committees show a significant negative relationship with IFD. The rest of the variables do not show significant relationship with the extent of IFD (see Table 5).

Table 5

Multiple Regression Analysis of Determinants of Internet Financial Disclosure

\begin{tabular}{|c|c|c|c|c|}
\hline Independent Variables & $\begin{array}{l}\text { Predicted } \\
\text { Sign }\end{array}$ & Coefficients & t-statistics & VIF \\
\hline \multicolumn{5}{|l|}{ Company characteristics } \\
\hline Internationality & + & 0.053 & .947 & 1.061 \\
\hline Leverage & + & 0.068 & 1.209 & 1.065 \\
\hline Foreign shareholders & + & -0.049 & -.838 & 1.151 \\
\hline IT experts & + & 0.312 & $5.434^{* * *}$ & 1.118 \\
\hline Firm's is age & + & 0.250 & $4.217^{* * *}$ & 1.191 \\
\hline No of shareholders & + & 0.217 & $3.635^{* * *}$ & 1.207 \\
\hline Listing status & + & 0.204 & $3.490^{* * *}$ & 1.156 \\
\hline \multicolumn{5}{|l|}{$\begin{array}{l}\text { Dominant personality in Board } \\
\text { committees }\end{array}$} \\
\hline $\begin{array}{l}\text { Chairman of Company and Audit } \\
\text { Committee }\end{array}$ & $?$ & -.051 & -.616 & 2.302 \\
\hline $\begin{array}{l}\text { Chairman of Audit and Nomination } \\
\text { Committees }\end{array}$ & $?$ & .112 & 1.264 & 2.675 \\
\hline $\begin{array}{l}\text { Chair. of Com, Audit and Nomination } \\
\text { Committees }\end{array}$ & $?$ & -.213 & $-3.355^{* * *}$ & 1.363 \\
\hline Constant & & & -3.324 & \\
\hline ANOVA & 0.000 & & & \\
\hline Durbin Watson & 1.838 & & & \\
\hline Std. Error & 3.531 & & & \\
\hline F Value & 16.202 & & & \\
\hline Sig. F & 0.000 & & & \\
\hline R Square & 0.478 & & & \\
\hline Adjust R Square & 0.448 & & & \\
\hline
\end{tabular}

*** significant at $1 \%$ level ** significant at $5 \%$ level * significant at $10 \%$ level

20 IJMS 18 (1), 1-29 (2011) 
The productive ability of analysis is $\mathrm{R}^{2}=0.478$ and adjusted $\mathrm{R}^{2}=0.448$ which is respectable.

\section{Discussion}

The above results suggest that a company's characteristic variables which are IT experts, firm's age, number of shareholders, listing status and dominant personalities in the audit and nomination committees are significant variables for the extent of IFD in Malaysia. This finding is not surprising for several of reasons. Firstly, since the paper investigates Internet disclosure (the most advanced technology in communication) it is expected that the companies that have many IT experts are more likely to disclose more financial information through their websites. Secondly, old companies are more familiar with Internet disclosure than recent companies. Based on the signalling theory, old firms are generally disclosing more information in order to differentiate themselves from the newcomers on the stock exchange (Morris, 1987; Watts \& Zimmerman, 1986; Skinner, 1994). In addition, as the old firms have more control over the market, they are in a better position to provide reliable forecasts (Hughes, 1986). Therefore, it is normal to observe that old companies disclose more financial information than new companies. Thirdly, it is logical to observe that the number of shareholders has a significant positive relationship with IFD since the Internet has wide coverage and low reporting-cost compared to other printing media. These advantages in turn, motivate the companies that have a large number of shareholders to use the Internet as a medium for disseminating their financial information.

Fourthly, listing status is a new variable and has never been tested before in previous studies. The results of regression analysis indicate that if the companies are listed on the main board of Bursa Malaysia, they are more likely to have websites to disclose more financial information on them than their counterparts on the second board. In other words, there is a gap between the companies that are listed on the main board and the companies that are listed on the second board. This gap in turn, influences the level of transparency and the usage of advanced technology such as the Internet. Nevertheless, it is not surprising to observe this phenomenon because of the different requirements of Bursa Malaysia in relation to the main and the second boards. The difference is because the companies listed on the main board usually are big companies (financial capital of more than RM60 million) and therefore capture more public and government concern 
in relation to the level of transparency, technology development and environment. This results in the policy makers of Bursa Malaysia to set more strict requirements and regulations for main board companies. Internet reporting is an option to fulfil all the requirements in a cheap and fast manner.

Last but not least, the results of regression analysis reveal that the level of IFD is negatively affected if the chairman of two committees (audit and nomination) is also the chairman of the company. In this case the chairman influences the independence of the two committees which in turn impede them from fulfilling their responsibilities effectively. This is normally followed by a low level of information being disclosed.

From the analysis, it can be seen that significant support can be found for hypotheses H4, H5, H6, H7 and H10, However, there is no support for hypotheses H1, H2, H3, H8 and H9. Nevertheless, information disclosure involves the human judgment element and therefore can never be explained completely by the company's characteristics. Within this context, however, the paper provides some evidence to support the signalling theory and the cost and benefit hypothesis in relation to disclosure.

\section{Conclusion}

This paper examines the relationship between ten variables and the extent of IFD by Malaysian-listed companies. The results provide evidence that there is a significant positive relationship between IT experts, firm's is age, number of shareholders, and listing status, and the extent of IFD. However, dominant personalities in the audit and the nomination committees affect the level of IFD in a negative manner. The rest of the variables did not show any significant relationship with IFD. From the results it is suggested that the Malaysian government should give more attention to the issue of dominant personalities in the audit and the nomination committees in order to boost IFD. The criteria for the appointment of the chairmen of the audit and the nomination committees should also be regulated by the government agencies involved. In short, the results of this research highlight several characteristics that can be exploited to promote transparency and technology usage. The regulatory bodies can also make IFD as mandatory. All these can assist the Malaysian government in realizing its ambition to be a developed nation by 2020 . 
Due to limited time and cost, this study has examined the level of IFD cross-sectionally using 2005 data. The limitation of this method is that it ignores any changes in the level of financial disclosure from one year to another. In other words, any increase of decrease on the level of disclosure (as it is voluntary in nature) will not be considered in the cross-sectional method as it only measures the level of disclosure for the year of study. This results in the findings being not hundred percent accurate and reliable. More robust results could be obtained by using the longitudinal study approach. It is important to examine whether time plays any role on the IFD.

\section{References}

Abdul Samad, F. (2002). Ownership structure in the Malaysian corporation sector: Its impact on corporate governance, performance, financing and investment patterns. Institute for Development Policy and Management Working Paper, University of Manchester.

Ahmed, K., \& Nicholls, D. (1994). The impact of non-financial company characteristics on mandatory disclosure compliance in developing countries: The case of Bangladesh. The International Journal of Accounting, 29(1), 62-77.

Allam, A., \& Lymer, A. (2003). Developments in Internet financial reporting: Review and analysis across five developed countries. International Journal of Digital Accounting Research, 3(6), 165-200.

Alsaeed, K. (2005). The association between firm-specific characteristics and disclosure: The case of Saudi Arabia. Managerial Auditing Journal, 21(5), 476-489.

Archambault J. J., \& Archambault, M. A. (2003). A multinational test of determinants of corporate disclosure. The International Journal of Accounting, 3(38), 173-194.

Ashbaugh, H., Johnstone, K. M., \& Warfield, T. D. (1999). Corporate reporting on the Internet. Accounting Horizons, 13(3), 241-257.

Botosan, C. A. (1997). Disclosure level and the cost of equity capital: Disclosure, liquidity and the cost of capital. Journal of Finance, 46(4), 1325-1359.

Bureau, D., \& Raffournier, B. (1989). Some determinants of accounting choices for consolidated statements of French firms: The case of pension costs engagement. Paper presented at the 12th EAA Congress, Stuttgart.

Bursa Malaysia. (2010). Listing requirements of Bursa Malaysia Securities Berhad. Retrieved from http://www.bursamalaysia.com

Camfferman, K., \& Cooke, T. E. (2002). An analysis of disclosure in the annual reports of UK and Dutch companies. Journal of International Accounting Research, 1(1), 3-30. 
Chen, C. J. P., \& Jaggi, B. (2000). Association between independent non-executive directors, family control and financial disclosures in Hong Kong. Journal of Accounting and Public Policy, 19(4\&5), 285-310.

Chow, C. W., \& Boren, W. A. (1987). Voluntary financial disclosure by Mexican corporations. The Accounting Review, 62(3), 533-541.

Chtourou, S. M., Bedard, J., \& Courteau, L. (2001). Corporate governance and earnings management. Social Science Research Network.

Claessens, S., Djankov, S., \& Lang, L. (2000) the Separation of ownership and control in East Asian corporations. Journal of Financial Economics, 58, 81-112.

Clarkson, M. B. E. (1995). A stakeholder framework for analyzing and evaluating corporate social performance. The Academy of Management Review, 20(1), 92-117.

Cohen, J., Gaynor, L. M., Krishnamoorthy, G., \& Wright, A. M. (2007). Auditor communications with the audit committee and the board of directors: Policy recommendations and opportunities for future research. Accounting Horizons, 21(2), 165.

Collier, P. (1997). Corporate governance and audit committees: Current issues in auditing (3rd ed.). London: Paul Chapman Publishing.

Cooke, T. E. (1989). Voluntary corporate disclosure by Swedish companies. Journal of International Financial Management and Accounting, 1(2), 171-195.

Cooke, T. E. (1992). The impact of size, stock market listing and industry type: Disclosure in the annual report of Japanese listed corporations. Accounting and Business Research, 87(4), 221-237.

Craven, B. M., \& Marston, C. L. (1999). Financial reporting on the Internet by leading UK companies. The European Accounting Review, 8(2), 321-333.

Da Silva, W. M., \& De Lira Alves, L. (2004). The voluntary disclosure of financial information on the Internet and the firm value effect in companies across Latin America. Paper presented at the 13th International Symposium on Ethics, Business and Society, January.

Debreceny, R., Gray, G. L., \& Rahman, A. (2002). The determinants of Internet financial reporting. Journal of Accounting and Public Policy, 21(4\&5), 371-394.

Diamond, D., \& Verrecchia, R. (1991). Disclosure, liquidity and the cost of equity capital. Journal of Finance, 56(4), 1325-1360.

Dichev, L., \& Skinner, D. (2002). Large-sample evidence on the debt covenant hypothesis. Journal of Accounting Research, 40(4), 1091-1124.

24 IJMS 18 (1), 1-29 (2011) 
Ettredge, M., Richardson, V. J., \& Scholz, S. (2002). Dissemination of information for investors at corporate websites. Journal of Accounting and Public Policy, 21(4-5), 357-369.

Frankel, R., Johnson, M., \& Skinner, D. J. (1999). An empirical examination of conference calls as a voluntary disclosure medium. Journal of Accounting Research, 37(1), 133-150.

Garcia-Benau, M. A., \& Monterrey-Mayoral, J. (1992). Voluntary financial disclosure by listed Spanish companies: Extent and corporate characteristics. Paper presented at the 15th EAA Congress, Madrid.

Groff, J. E., \& Pitman, M. K. (2004). Municipal financial reporting on the world wide web: A survey of financial data displayed on the official websites of the 100 largest U.S. municipalities. The Journal of Government Financial Management, 2(53), 2-22.

Gul, F. A., \& Leung, S. (2004). Board leadership, outside directors' expertise and voluntary corporate disclosures. Journal of Accounting and Policy, 23(5), 351-379.

Hair Jr., J. F., Anderson, R. E., Tatham, R. L., \& Black, W. C. (1998). Multivariate data analysis. New Jersey: Prentice Hall.

Haniffa, R., \& Cooke, T. (2002). Culture, corporate governance and disclosure in Malaysian corporations. ABACUS, 38(3), 317-349.

Haron, H., Jantan, M., \& Pheng, E. G. (2005). Audit committee compliance with Kuala Lumpur Stock Exchange listing requirements. International Journal of Auditing, 9(3), 187-200.

Hashim, F., \& Mohd Saleh, N. (2007). Voluntary annual report disclosures by Malaysian multinational corporations. Malaysian Accounting Review, 6(1), 129-151.

Hassan, A., Jaffer N., \& Johi, S. K. (1999). Financial reporting on the Internet by Malaysian companies: Perceptions and practices. Asia-Pacific Journal of Accounting, 6(2), 299-319.

Healy, P. M., Hutton, A. M., \& Palepu, K. G. (1999). Stock performance and intermediation changes surrounding sustained increases in disclosure. Contemporary Accounting Research, 16(3), 485-520.

Ho, S. S. M., \& Shun Wong, K. (2001). A study of the relationship between corporate governance structures and the extent of voluntary disclosure. Journal of International Accounting, Auditing and Taxation, 10(2), 139-156.

Hossain, M., Tan, L. M., \& Adams, M. (1994). Voluntary disclosure in an emerging capital market: Some empirical evidence from companies listed on the Kuala Lumpur Stock Exchange. The International Journal of Accounting, 29(4), 334-351.

Hughes, P. J. (1986). Signalling by direct disclosure under asymmetric information. Journal of Accounting and Economics, 8(2), 119-142. 
Hurtt, D. N., Kreuze, J. G., \& Langsam, S.A. (2001). Using the Internet for financial reporting. The Journal of Corporate Accounting $\mathcal{E}$ Finance, 12(3), 67-75.

Joshi, P. L., \& Jawaher Al-Modhahki. (2003). Financial reporting on the Internet: Empirical evidence from Bahrain and Kuwait. Asia Review of Accounting, 11(1), 88-101.

Katsuhiko, K., Akihiro, N., Yasushi, O., \& Tomomi, S. (2001). Determinants of environmental report publication in Japanese companies. Paper presented at the 3rd APIRA Conference, Adelaide, Australia.

Khadaroo, M. I. (2005). Business reporting on the Internet in Malaysia and Singapore: A comparative study. Corporate Communications: An International Journal, 10(1), 58-68.

King, R., Pownall, G., \& Waymire, G. (1990). Expectation adjustment via timely management forecasts: Review synthesis and suggestions for future research. Journal of Accounting Literature.

Kreps, D. M. (1990). A course in microeconomic theory. New York: Harvester Wheatsheaf.

Ku Nor Izah, K. I. (2003). The usefulness of quarterly financial reporting in Malaysia (Unpublished doctoral dissertation). Cardiff University.

Lam, K., Mok, H. M. K., Cheung, I., \& Yam, H. C. S. (1994). Family groupings on performance of portfolio selection in the Hong Kong stock market. Journal of Banking and Finance, 18(4), 725742.

Lang, M. H., \& Lundholm, R. J. (1996). Corporate disclosure policy and analyst behavior. The Accounting Review, 71(4), 467-492.

Laswad, F., Fisher, R., \& Oyelere, P. (2005). Determinants of voluntary Internet financial reporting by local government authorities. Journal of Accounting and Public Policy, 24(2), 101-121.

Leung, Morris R. D., \& Gray, S. J. (2005). Corporate transparency in China: Factors influencing financial disclosure levels. Paper presented at the 29th Annual Congress of the European.

Levitt, A. (1999). Quality information: The lifeblood of our marketing. The Economic Club of New York.

Lodhia, S. K. (2004). Corporate environmental reporting media: A case for the world wide web. Electronic Green Journal, 1(20).

Mangena, M., \& Pike, R. (2004). Shareholding of audit committee members, audit committee size and expertise and the quality of interim financial reporting. Bradford: Mimeo.

Marston C., \& Polei, A. (2004). Corporate reporting on the Internet by German companies. International Journal of Accounting Information Systems, 5(3), 285-311.

26 IJMS 18 (1), 1-29 (2011) 
Marston, C. (2003). Financial reporting on the Internet by leading Japanese companies. Corporate Communications: An International Journal, 8(1), 23-34.

Meek, G. K., Roberts, C. B., \& Gray, S. J. (1995). Factors influencing voluntary annual report disclosures by US, UK and Continental European multinational corporations. Journal of International Business Studies, 26(3), 115-131.

Mitchell, W., Ho, W., \& Pei, C. (2000). Corporate social disclosures by listed companies on their websites: An international comparison. Hong Kong Polytechnic University.

Mohammed, R., Mohamed, A., \& Mohamed, M. (2003). Internet financial reporting (IFR) in Malaysia: A survey of contents and presentations. Sintok: Universiti Utara Malaysia.

Mok, H. M. K., Lam, K., \& Cheung, I. (1992). Family control and return covariation in Hong Kong's common stocks. Journal of Business Finance \& Accounting, 3(2), 277-293.

Moonitz. M. (1961). The basic postulates of accounting. Accounting Research Study, AICPA, New York, 1.

Morris, R. D. (1987). Signalling, agency theory and accounting policy choice. Accounting and Business Research, 18(69), 47-56.

Naser, K., Al-Khatib, K., \& Karbhari, Y. (2002). Empirical evidence on the depth of corporate information disclosure in developing countries: The case of Jordan. International Journal of Commerce and Management, 12(3), 122-155.

Nazli A. Mohd Ghazali. (2008). Voluntary disclosure in Malaysian corporate annual reports: Views of stakeholders. Social Responsibility Journal, 4(4), 504-516.

Noor Azizi, A. I., Mahamad, T., \& Adon, I. (2000). Financial reporting disclosure on the Internet by Malaysian-listed companies. Akauntan Nasional, 1(1), 28-33.

Oyelere, P., Laswad, F., \& Fisher, R. (2003). Determinants of Internet financial reporting by New Zealand companies. Journal of International Financial Management and Accounting, 14(1), 26-63.

Pirchegger, B., \& Wagenhofer, A. (1999). Financial information on the Internet: A survey of the homepages of Australian companies. European Accounting Review, 8(2), 383-395.

Portes, R., \& Rey, H. (2005). The determinants of cross-border equity flows. Journal of International Economics, 65(2), 269-296.

Raffournier. B. (1995). The determinants of voluntary financial disclosure by Swiss-listed companies. The European Accounting Review, 4(2), 261-280.

Richardson A. J., \& Welker, M. (2001). Social disclosure, financial disclosure and the cost of equity capital. Accounting Organizations and Society, 26(7), 597-616. 
Roberts. (1992). Determinants of corporate social responsibility disclosure: An application of stakeholder theory. Accounting, Organizations and Society, 17(6), 595-612.

Sekaran, U. (2003). Research methods for business: A skill building approach (3rd ed.). Singapore: John Wiley \& Sons.

Sekaran, U. (2003). Research methods for business: A skill building approach (4th ed.). Singapore: John Wiley \& Sons.

Shivdasani, A., \& Yermack, D. (1999). CEO involvement in the selection of new board members: An empirical analysis. The Journal of Finance, 54(5), 1829-1853.

Skinner, D. J. (1994). Why firms voluntarily disclose bad news. Journal of Accounting Research, 32(1), 38-60.

Susanto, D. (1992). An empirical investigation of the extent of corporate disclosure in annual reports of companies listed on the Jakarta Stock Exchange. University Microfilms International.

Tariq, H. I. (2001). An empirical investigation of factors influencing voluntary disclosure of financial information on the Internet in the GCC Countries. Qatar University.

Vafeas, N. (1999). The nature of board nominating committees and their role in corporate governance. Journal of Business Finance $\mathcal{E}$ Accounting, 26(1-2), 199-225.

Wallace, R. S. O., Naser, K., \& Mora, A. (1994). The relationship between the comprehensiveness of corporate annual reports and firm characteristics in Spain. Accounting and Business Research, 25(97), 41-53.

Watts, R. L., \& Zimmerman, J. L. (1986). Positive accounting theory. New Jersey: Englewood Cliffs.

Welker, M. (1995). Disclosure policy, information asymmetry, and liquidity in equity markets. Contemporary Accounting Research, 11(2), 801-828.

Wheeler D., \& Elkington J. (2001). The end of the corporate environmental report? Or the advent of cybernetic sustainability reporting and communication. Business Strategy and the Environment, 10(1), 1-14.

Wong, N. L. (1996). Easing down the merit-disclosure continuum: A case study of Malaysia and Taiwan. Law and Policy in International Business, 28(1), 24-39.

Xiao, J. Z., Yang, H., \& Chow, C. W. (2004). The determinants and characteristics of voluntary Internet-based disclosures by listed Chinese companies. Journal of Accounting and Public Policy, 23(3), 191-225.

Yatim, P., Kent, P., \& Clarkson, P. (2006). Governance structures, ethnicity, and audit fees of Malaysian-listed firms. Managerial Auditing Journal, 21(7), 757-782.

28 IJMS 18 (1), 1-29 (2011) 
Yeo, G. H. H., \& Ziebart, D. A. (1995). An empirical test of the signalling effect of management earnings forecasts: A decomposition of the earnings surprise and forecast surprise effects. Journal of Accounting, Auditing \& Finance, 10(4), 787-802. 